\title{
Gingival Hypertrophy in a Child with Hyaline Fibromatosis Syndrome
}

\section{Gingivna hipertrofija u djeteta s hijalinim fibromatoznim sindromom}

\author{
${ }^{1}$ Department of Maxillofacial and Oral Surgery, University Hospital Dubrava, Zagreb, Croatia \\ Klinika za kirurgiju lica, čeljusti i usta Kliničke bolnice Dubrava, Zagreb, Hrvatska \\ 2 University of Zagreb School of Dental Medicine, Zagreb, Croatia \\ Stomatološki fakultet Sveučilišta u Zagrebu, Zagreb, Hrvatska \\ ${ }^{3}$ University of Zagreb School of Medicine, Zagreb, Croatia \\ Medicinski fakultet Sveučilišta u Zagrebu, Zagreb, Hrvatska \\ ${ }^{4}$ Kustec Dental Polyclinic, Zagreb, Croatia \\ Stomatološka poliklinika Kustec, Zagreb, Hrvatska
}

Received: December 26, 2019

Accepted: March 1, 2020

Address for correspondence Marko Tarle, M.D.

Department of Maxillofacial and Oral Surgery,

University Hospital Dubrava

University of Zagreb School of

Medicine

Ave. Gojko Šušak 6

10000 Zagreb, Croatia

Phone: 0038512903431

tarlemarko1@gmail.com

Key words

Systemic Hyalinosis; Gingival Hypertrophy; Gingivectomy; Extracellular

Matrix; ANTXR2 gene

\section{Introduction}

Hyaline fibromatosis syndrome (HFS) is an extremely rare autosomal recessive disorder which appear in infancy or childhood. It is characterized by excessive deposition of amorphous hyaline substance in numerous tissues and organs, with the exception of brain tissue. HFS is caused by a mutation of the ANTXR2 gene (Anthrax Toxin Receptor - 2) located on chromosome 4q21, which encodes a transmembrane cell receptor that participates in strengthening and supporting connective tissue by reacting with the extracellular matrix (1). This transmembrane protein is called CMG2 (Capillary Morphogenesis Protein Gene - 2) and has four components. The extracellular component of the receptor consists of the von Willebrand type A domain (vWA), which continues to the immunoglobulin-like domain, followed by the transmembrane domain and finally the intracellular cytoplasmic tail (2).
Uvod

Hijalini fibromatozni sindrom (HFS) iznimno je rijedak autosomno recesivni poremećaj koji se pojavljuje kod dojenčadi i djece. Karakterizira ga prekomjerno odlaganje amorfne hijaline tvari u mnogobrojnim tkivima i organima, osim moždanoga tkiva. HFS je uzrokovan mutacijom gena ANTXR2 (engl. Anthrax Toxin Receptor - 2) smještenog na kromosomu 4q21 koji kodira transmembranski stanični receptor čija je zadaća sudjelovanje u jačanju i podržavanju vezivnoga tkiva reagirajući s ekstracelularnim matriksom (1). Taj transmembranski protein naziva se još i CMG2 (engl. Capillary Morphogenesis Protein Gene - 2), a sastoji se od četiriju komponenti. Izvanstanični dio receptora čini von Willebrandov tip A domene (vWA) na koju se nastavlja domena slična imunoglobulinu, zatim transmembranska domena te naposljetku unutarstanični citoplazmatski rep (2). ANTXR2 dobio je naziv 
ANTXR2 was named after primarily being discovered as a receptor for the anthrax toxin of Bacillus anthracis. The pathogenesis of HFS has not been fully explained, but it seems that the mutation of the ANTXR2 causes the synthesis of a receptor that has impaired ability to interact with extracellular matrix components, leading to the accumulation of hyaline deposits in tissues (3). The first clinical signs may be present at birth or appear during infancy. Given the time of the disease onset, the severity of the clinical picture and survival, two syndromes with similar clinical presentation and pathological findings were described in the literature: Infantile Hyaline Fibromatosis (IHF) and Juvenile Hyaline Fibromatosis (JHF). IHF occurs earlier with more pronounced clinical picture and shorter survival, whereas JHF develops later, with milder clinical picture and longer survival. Today, after the discovery of a common genetic cause, it is clear these are stages of the same disease. In 2012, HFS was classified into 4 stages, according to severity, incidence, and survival $(1,4)$. Multiple nodular subcutaneous lesions, painful progressive joint contractures, hyperpigmentation of the skin, enteropathy with extensive protein loss and chronic diarrhea, frequent infections, bone lesions, gingival hypertrophy and thickening of the lip and cheek tissue belong to the characteristic manifestations of HFS (4). In this report we present a five-year-old girl with HFS who, to the best of our knowledge, is the first patient in Croatia with a confirmed ANTXR2 gene mutation described in the literature.

\section{Case report}

A 5-year-old girl was referred to the Department of Maxillofacial and Oral Surgery from the pediatric clinic having the chief complaint of difficulty feeding and speaking due to extensive generalized gingival hypertrophy. She was previously diagnosed with HFS, during early infancy. Although she was born in the third trimester of pregnancy, there was an increased risk for preterm delivery managed by medications. The baby was born after full term pregnancy, without complications during delivery. The family history revealed no similar illnesses. The non-consanguineous parents already had one healthy female child. The first symptoms appeared at the age of two months, in the form of upper extremities joint stiffness. This progressed to joint contractures (Figure 1.A). At the age of two years, the patient presented hyperpigmented macules over bony prominences and stunted growth, hypotonia with normal cognitive development (Figure 1.B). As the disease progressed further, pink pearly skin papules appeared on the skin of the neck, condyloma-like growths in the perianal region, and subcutaneous nodules on the trunk and lower extremities (Figure 1.C). A biopsy of the skin and subcutaneous nodules revealed a normal structure of the epidermis and dermis with hyaline deposits in the subcutaneous tissue along with multiplied fibroblasts and blood vessels. A molecular analysis confirmed the mutation of the ANTXR2 gene. The patient underwent orthopedic correction of knee contractures at the age of three.

During a clinical examination of the head and neck, skeletal deformities of viscerocranium and neurocranium (broad prema tome što je primarno otkriven kao receptor za antraks, toksin bakterije Bacillus anthracis. Patogeneza HFS-a nije razjašnjena, no vjeruje se da mutacija gena ANTXR2 rezultira sintezom receptora koji ima oslabljeno svojstvo interakcije s komponentama ekstracelularnog matriksa te potiče akumuliranje hijalinih depozita u tkivima (3). Prvi klinički znakovi mogu se pojaviti pri rođenju djeteta ili u dojenačkoj dobi. $S$ obzirom na vrijeme pojave bolesti, težinu kliničke slike i preživljenje, u literaturi su se opisivala dva sindroma sa sličnom kliničkom slikom i patohistološkim nalazom - infantilna hijalina fibromatoza (IHF) i juvenilna hijalina fibromatoza (JHF). IHF se pojavljuje ranije s izraženijom kliničkom slikom i kraćim preživljavanjem, a JHF je sporiji i ima blažu kliničku sliku i dulje preživljavanje. Danas, nakon otkrića zajedničkoga genetskog uzroka, jasno je da je riječ o stadijima iste bolesti. Godine 2012. HFS je klasificiran u četiri stadija s obzirom na težinu kliničke slike, pojavnost i preživljavanje $(1,4)$. Multiple nodularne potkožne lezije, bolne progresivne kontrakture zglobova, hiperpigmentacije na koži, enteropatija s ekstenzivnim gubitkom proteina i kroničnim proljevima, česte infekcije, koštane lezije, hipertrofija gingive, zadebljanja tkiva usana i obraza, karakteristične su manifestacije HFS-a (4). U ovom radu opisujemo petogodišnju djevojčicu oboljelu od HFS-a i to je, prema našim spoznajama, ujedno i prvi takav slučaj s potvrđenom mutacijom gena ANTXR2 opisan u Hrvatskoj.

\section{Prikaz slučaja}

Djevojčica u dobi od pet godina upućena je iz Klinike za pedijatriju u Kliniku za kirurgiju lica, čeljusti i usta, a razlog je bio otežano hranjenje i govorenje zbog opsežne generalizirane gingivne hipertrofije obiju čeljusti. U ranoj dojenačkoj dobi dijagnosticiran joj je HFS. Rođena je prirodnim putem u terminu, no u trećem tromjesečju trudnoća je bila zakomplicirana prijetećim prijevremenim porođajem i održavana je lijekovima. Slične bolesti nisu zabilježene u užoj i široj obitelji. Roditelji nisu u krvnom srodstvu te već imaju jednu zdravu djevojčicu. U dobi od dva mjeseca kod djeteta je zapažena ograničena pokretljivost zglobova gornjih ekstremiteta koja je postupno prešla u kontrakturu zglobova (slika 1. A). $\mathrm{U}$ dobi od dvije godine pacijentica je imala hiperpigmentacije na koži iznad koštanih prominencija te zastoj u rastu i razvoju, uz normalan kognitivni razvoj (slika 1. B). Kako je bolest napredovala, pojavile su se kožne biserne papule na vratu, promjene slične kondilomima u perianalnoj regiji, te multiple nodularne potkožne lezije na trupu i donjim ekstremitetima (slika 1. C). U sklopu dijagnostičke obrade učinjena je biopsija kožnih i potkožnih lezija kojom se otkrila normalna struktura epidermisa i dermisa s pojavom obilne količine hijalinih depozita u potkožnom tkivu uz umnožene fibroblaste i krvne žile. Molekularnom analizom potvrđena je mutacija gena ANTXR2. $S$ tri godine pacijentica je operirana zbog kontraktura koljena.

Kliničkim pregledom glave i vrata pronađene su skeletne deformacije viscerokranija i neurokranija (široko čelo, sedlasti korijen nosa, nisko položene uške) (slika 1. D). Intraoral- 

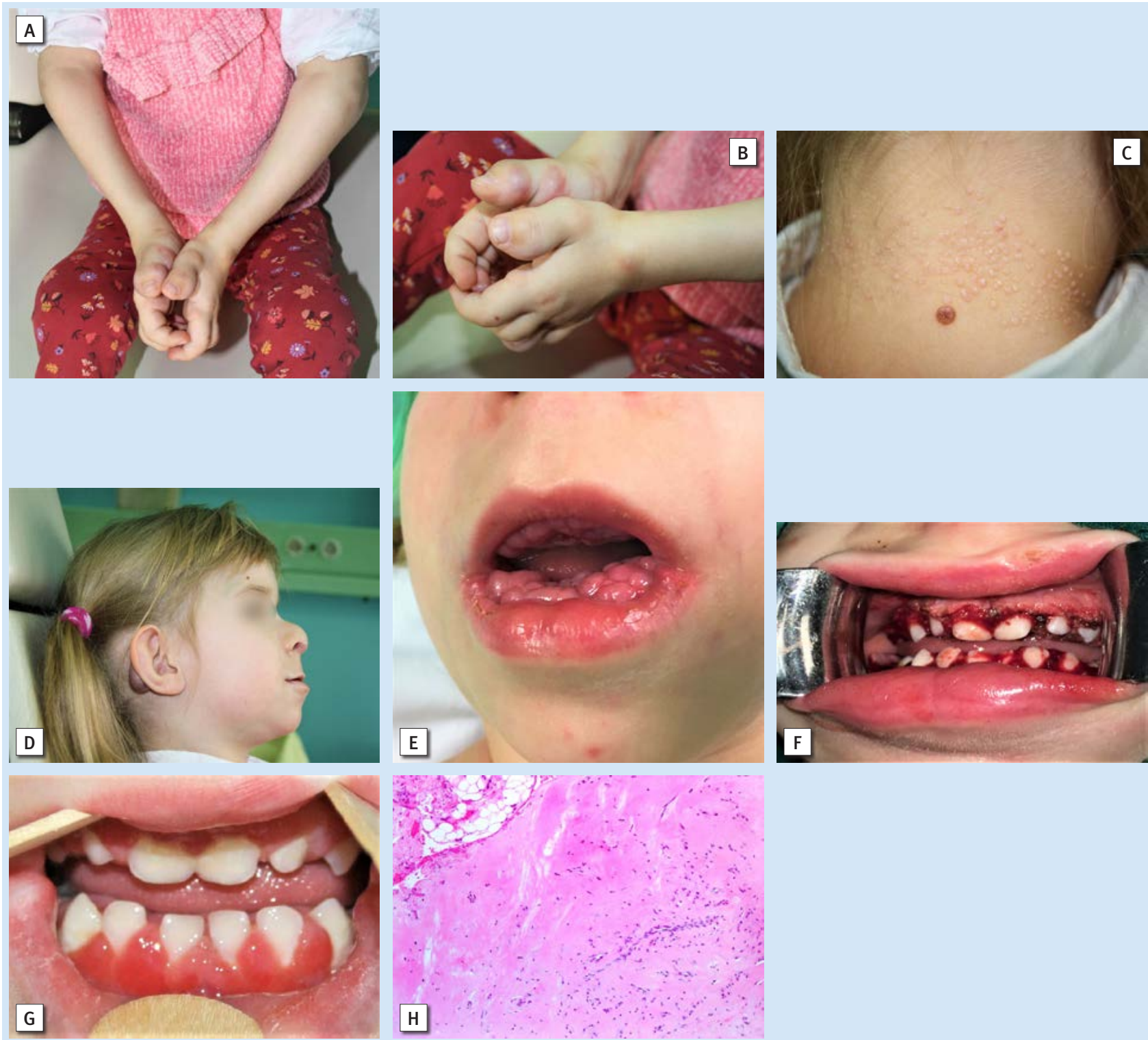

Figure 1 Five year old patient with Hyaline Fibromatosis Syndrome (HFS).

Slika 1. Petogodišnja djevojčica s hijalinim fibromatoznim sindromom (HFS-om)

A. Limited joint movements: flexion deformity of elbows, wrists and small joints of both hands.

A. Ograničena pokretljivost zglobova: fleksorne deformacije laktova, zapešća i malih zglobova šaka

B. Hyperpigmented macules over bony prominences of the joints and multiple subcutaneous nodules.

B. Hiperpigmentirane makule iznad koštanih prominencija zglobova i multipli potkožni čvorovi

C. Pearly papules on the back side of the neck.

C. Biserne papule na koži nuhalne regije vrata

D. Facial profile showing depressed nasal bridge and low set ears. Retroauricular subcutaneous nodule behind the right ear.

D. Profil lica sa sedlastim korijenom nosa i nisko položenim uškama; vidljiv je potkožni čvor iza desnog uha

E. Preoperative appearance of generalized gingival hypertrophy of both jaws completely covering the teeth.

E. Prijeoperacijski izgled generalizirane hipertrofije gingive obiju čeljusti koja prerasta zube

F. Early postoperative status after surgical gingivectomy with intact deciduous teeth.

F. Rani poslijeoperacijski nalaz nakon kirurške gingivektomije $s$ urednim statusom mliječne denticije

G. Clinical appearance of the gingiva 1 year after the procedure.

G. Klinički nalaz gingive godinu dana nakon operacije

H. Pathological specimen of excised gingiva showing accumulation of eosinophilic hyaline deposit in intercellular space.

H. Patohistološki nalaz ekscidirane gingive pokazuje obilnu nakupinu amorfne hijaline tvari u međustaničnom prostoru

forehead, depressed nasal bridge, low set ears) were recorded (Figure 1.D). An intraoral clinical examination showed a limited mouth opening due to diffusely thickened skin of the oral commissures and extensive gingival hypertrophy that completely covered the crowns of the teeth (Figure 1.E). nim pregledom zapaženo je ograničeno otvaranje usta zbog difuznog zadebljanja kože komisure usana te opsežna gingivna hipertrofija u objema čeljustima koja je potpuno prekrivala krune zuba (slika 1. E). 
Due to the functional impairments, a gingivectomy with electrocautery was performed, in general endotracheal anesthesia, resulting in satisfactory postoperative appearance, with healthy deciduous teeth (Figure 1.F and 1.G). During the same anesthesia, subcutaneous nodules from the lower extremities were removed by a plastic surgeon.

\section{Discussion}

J. Murray (1873) was the first to mention HFS, under the name of "molluscum fibrosum" as an unusual form of neurofibromatosis (5). B. Puretić et al. (1962) described a patient with similar manifestations and named the disease mesenchymal dysplasia. For the years to come, different names have been used for the same disease, until Y. Kitano (1972) concluded that it was the same syndrome with variable clinical presentation and introduced the term hyaline fibromatosis (3). To date, 84 cases of HFS have been described in the literature. It is equally common in males and females. Forty six ANTXR2 gene mutations have been identified so far, divided into four classes, depending on the receptor domain affected by the mutation. Recent studies showed that mutations affecting the transmembrane, immunoglobulin-like domain and von Willebrand type A domain cause a more severe disease (formerly called IHF), while mutations in the gene responsible for the intracellular part of ANTXR2 receptor cause milder disease (formerly referred to as JHF) with later onset, milder clinical presentation and longer survival (4). In 2012, R. Denadai et al. developed a 4-grade classification system. The first stage is the mildest form of the disease and involves skin changes and gingival hypertrophy. In the second stage, changes in the joints and bones are present, while in the third stage, the internal organs are affected. The fourth stage is the most severe (severely shortened life expectancy). It is, usually, diagnosed earlier than the first three stages, during the first three months of life, the first symptom being joint stiffness. The median survival in stage 4 is 15 months (6). Although our patient was diagnosed very early, at the age of two months, internal organs were not affected which would indicate that her condition is most likely stage two.

Clinically, the two most common manifestations are subcutaneous nodules $(85.7 \%)$ and gingival hypertrophy (92.9\%). Although subcutaneous nodules are most often found on the scalp, they were present only on the hands of our patient, on her feet and behind her ears. In the majority of cases reported in the literature these signs were the ones that led to the diagnosis (4).

Gingival hypertrophy results in impaired oral hygiene that can cause odontogenic infections and difficulties in feeding. Our patient had great difficulties in eating, however, gingival hypertrophy didn't cause tooth decay. Perhaps, the fact that the gingiva covered the entire crowns of the teeth completely acted as a protective mechanism. Hypertrophic gingiva was enlarged but painless, hard and normal in color. Gingival hypertrophy can cause difficulties in permanent teeth eruption. In older children, it can cover the entire occlusal surfaces of the teeth, causing difficulty in chewing and speaking. As a part of HFS, gingival hypertrophy can be localized
Zbog poremećaja funkcije u općoj endotrahealnoj anesteziji učinjena je gingivektomija elektrokauterom, uz zadovoljavajući postoperativni nalaz sa zdravom mliječnom denticijom (slika 1. F i 1. G). U istom zahvatu plastični je kirurg uklonio potkožne čvorove s donjih ekstremiteta.

\section{Rasprava}

HFS prvi put u literaturi spominje J. Murray 1873. godine pod nazivom mollusum fibrozum kao neobičnu formu neurofibromatoze (5). Godine 1962. B. Puretić i suradnici opisali su pacijenta sa sličnim manifestacijama te su bolest nazvali mezenhimalna displazija. Godinama su se upotrebljavali različiti nazivi za istu bolest, dok Y. Kitano 1972. nije zaključio da je riječ o istom sindromu s varijabilnom kliničkom slikom te je uveo pojam hijalina fibromatoza (3). U literaturi su dosad opisana 84 slučaja pacijenata oboljelih od HFS-a. Podjednako je čest u oba spola. Danas je poznato 46 mutacija gena ANTXR2 koje se klasificiraju u četiri razreda, ovisno o domeni receptora koja je pogođena mutacijom. Prema najnovijim spoznajama mutacije koje zahvaćaju transmembransku domenu i domenu sličnu imunoglobulinu te von Willebrandov tip A domenu uzrokuju teži oblik bolesti (prije nazvan IHF), a mutacije gena za unutarstanični dio receptora ANTXR2 uzrokuju blaži oblik bolesti (prije nazvan JHF) s kasnijom pojavom simptoma, blažom kliničkom slikom i dužim preživljenjem (4). R. Denadai razradio je sa svojim suradnicima 2012. godine sustav stupnjevanja težine bolesti u četiri stadija od kojih je četvrti najtě̌i (iznimno skraćen životni vijek). Prvi stadij je najblaži oblik bolesti i uključuje promjene na koži i hipertrofiju gingive. U drugom stadiju pojavljuju se promjene na zglobovima i kostima, a u trećem su zahvaćeni unutarnji organi. Četvrti stadij je najteži te se dijagnosticira ranije negoli prva tri, tijekom prva tri mjeseca života, a prvi simptom je najčešće ukočenost zglobova. Medijan preživljenja u četvrtom stadiju je 15 mjeseci (6). Iako je našoj pacijentici dijagnoza bila postavljena već $s$ dva mjeseca, bolest nije zahvatila unutarnje organe što bi upućivalo na to da se njezina bolest najvjerojatnije može uvrstiti u drugi stadij. Dvije najčšće manifestacije su potkožni čvorovi $(85,7 \%)$ i hipertrofija gingive $(92,9 \%)$, te su u većini slučajeva opisanih u literaturi ti znakovi upućivali na dijagnozu (4). Iako se potkožni čvorovi najčešće opisuju na vlasištu, kod naše pacijentice bili su samo na rukama, stopalima i retroaurikularno.

Gingivna hipertrofija rezultira otežanom oralnom higijenom koja može uzrokovati odontogene infekcije te poteškoće pri hranjenju. Naša pacijentica imala je velike poteškoće pri hranjenju, no kod nje gingivna hipertrofija nije uzrokovala karijes zuba. Možda je gingiva imala protektivni učinak na zube zbog činjenice da je potpuno prekrivala njihove krune. Hipertrofična gingiva bila je bezbolno uvećana, tvrda i normalne boje. Hipertrofija gingive može utjecati na otežano nicanje trajnih zuba. Kod starije djece može biti toliko izražena kao u našem slučaju, te prekrivati okluzalne površine zuba i uzrokovati poteškoće pri žvakanju hrane. Djeca često imaju poteškoće s govorom. U sklopu HFS-a, gingivna hipertrofija može biti lokalizirana ili generalizirana. Najčešće je lokalizi- 
or generalized. Hypertrophy is most commonly localized on the palatal side of the tuber of the upper jaw or the lingual side of the lower alveolar ridge $(7,8)$.

The characteristic pathological features are the accumulation of amorphous, eosinophilic hyaline substance in many tissues and organs as found in the presented case (Figure 1.H) (9). Although the composition and origin of the hyaline substance is not yet fully known, some studies indicate that mutation of the ANTXR2 gene, due to receptor dysfunction, leads to destabilization and dysregulation of extracellular matrix components. Type IV and VI collagen and laminin have been shown to be the major ligands of receptors, and, in case of ANTXR2 dysfunction, they accumulate in the extracellular space. In addition, there is a proliferation of spindle and inflammatory cells (4). Pathological differential diagnosis includes Farber disease, I-cell disease (mucolipidosis II), Pseudo-Hurler polydistrophy (mucolipidosis IIIa) and lipoid proteinosis of Urbach and Wiethe (7). Given that there is no cure for HFS today, treatment is symptomatic and involves surgical removal of the gingiva and subcutaneous nodules. Unfortunately, poor results have been reported in the literature using interferon alfa-2B, corticosteroids, penicillamine and methotrexate $(4,10)$. Due to the extreme rarity of HFS and the short life span of patients, there is no consensus on treatment modalities to date. The most common cause of death in HFS is persistent diarrhea, frequent infections, and organ failure (6). Due to the recurrence of gingival hypertrophy, additional surgery is needed; however there is no doubt that gingivectomy greatly improves the quality of life in these patients $(7,8)$. In our case, one year follow up shows satisfactory results without local recurrence. After the procedure, the patient gained weight which is significant considering her stunted growth.

Until the cure for HFS has been found, it is necessary to focus on a multidisciplinary approach in the diagnosis and treatment of these patients and provide psychological support for the family. Although these patients suffer from a range of symptoms, it is necessary to address gingival hypertrophy in the earliest opportunity to allow proper nutrition, which is imperative bearing in mind their slower growth and development.

\section{Conflict of interests}

The authors have no competing interests.

\section{Patient consent}

Written patient consent was obtained from the patient's family. rana na palatinalnoj strani tubera gornje čeljusti ili na lingvalnoj strani zubnog grebena donje čeljusti $(7,8)$.

Karakteristična patohistološka slika uključuje nakupljanje amorfne, eozinofilne hijaline tvari u mnogim tkivima i organima te je upravo takvu sliku imala i naša pacijentica (slika 1. H) (9). Iako dosad nije u cijelosti poznat sastav i podrijetlo hijaline tvari, u nekim se istraživanjima navodi da mutacija gena ANTXR2, zbog nefunkcionalnosti receptora, destabilizira i disregulira sastavnice ekstracelularnog matriksa. Dokazano je da su glavni ligand receptora kolagen tipa IV i VI te laminin, pa se u slučaju nefunkcionalnosti ANTXR2 nakupljaju u izvanstaničnom prostoru. Uz navedeno, prisutna je proliferacija vretenastih i upalnih stanica (4). Patohistološka diferencijalna dijagnoza uključuje nodularnu amiloidozu, generaliziranu fibromatozu, Faverovu bolest, Winchesterovu bolest, mukopolisaharidozu, neurofibromatozu i multisistemsku inflamatornu bolest (7). S obzirom na to da danas još ne postoji lijek za HFS, liječenje je simptomatsko i uključuje kirurško uklanjanje gingive i kožnih tvorbi. Nažalost, u literaturi su zabilježeni loši rezultati nakon primjene interferona alfa-2B, kortikosteroida, penicilamina i metotreksata (4, 10). Zbog iznimno rijetke pojave HFS-a i kratkoga životnog vijeka bolesnika, do danas nema konsenzusa o modalitetima liječenja. Najěčšći uzrok smrti je perzistentni proljev, učestale infekcije te zatajenje organa (6). Zbog recidiva gingivne hipertrofije potrebni su dodatni kirurški zahvati, no valja zaključiti da gingivektomija uvelike utječe na kvalitetu života takvih bolesnika $(7,8)$.U našem slučaju godinu dana nakon prvog zahvata stanje gingive zadovoljava, bez recidiva hipertrofije. Neposredno nakon gingivektomije pacijentica je počela dobivati na tjelesnoj težini, što je iznimno bitno ako se uzme u obzir dosadašnji usporeni rast.

Do pojave lijeka potrebno je usredotočiti se na multidisciplinarni pristup u dijagnostici i liječenju takvih bolesnika te pružati psihološku potporu užoj obitelji. Unatoč tomu što se ti pacijenti bore s mnoštvom simptoma, potrebno je gingivnu hipertrofiju tretirati što prije kako bi im se omogućila pravilna prehrana nužna za što bolji rast i razvoj koji je u HFS-u narušen.

\section{Sukob interesa}

Nije bilo sukoba interesa.

\section{Suglasnost}

Pismenu suglasnost dali su roditelji djevojčice. 


\section{Sažetak}

Hijalini fibromatozni sindrom (HFS) rijedak je autosomno recesivni genetski poremećaj koji karakterizira nakupljanje hijaline tvari u tkivima s kožnim, sluzničkim, koštanim, zglobnim i sistemskim manifestacijama. Bolest je uzrokovana mutacijom gena ANTXR2 koja rezultira sintezom neispravnog transmembranskog proteina, pa se hijalini depoziti prekomjerno talože u međustaničnom prostoru. Prvi znakovi mogu biti prisutni pri rođenju ili tijekom dojenačke dobi, a prvi simptom najčešće je ukočenost zgloba. Ostale manifestacije uključuju zglobne kontrakture, hiperpigmentirane makule kože iznad koštanih prominecija zglobova i hipertrofiju gingive, što je uz potkožne nodule (kvržice), vrlo često simptom koji potiče sumnju na HFS. Napredovanje bolesti uključuje enteropatiju s velikim gubitkom proteina, kroničnu dijareju i česte infekcije. U radu predstavljamo petogodišnju djevojčicu s teškim oblikom gingivne hipertrofije koja je uzrokovala poteškoće s hranjenjem i govorom. Prema našim spoznajama to je prvi pacijent opisan u Hrvatskoj s dokazanom mutacijom gena ANTXR2.
Zaprimljen: 26. prosinca 2019.

Prihvaćen: 1. ožujka 2020.

Adresa za dopisivanje

Marko Tarle, dr. med.

Klinika za kirurgiju lica, čeljusti i usta,

Klinička bolnica Dubrava

Medicinski fakultet Sveučilišta u

Zagrebu

Av. Gojka Šuška 6

10000 Zagreb, Hrvatska

tel: 0038512903431

tarlemarko1@gmail.com

Ključne riječi

sistemska hijalinoza; hipertrofija gingive; gingivektomija; izvanstanični matriks; gen ANTXR2

\section{References}

1. Hanks S, Adams S, Douglas J, Arbour L, Atherton DJ, Balci S, et al. Mutations in the gene encoding capillary morphogenesis protein 2 cause juvenile hyaline fibromatosis and infantile systemic hyalinosis. Am J Hum Genet. 2003 Oct;73(4):791-800.

2. Sun J, Collier RJ. Disulfide bonds in the ectodomain of anthrax toxin receptor 2 are required for the receptor-bound protective-antigen pore to function. PLoS One. 2010 May 10;5(5):e10553.

3. Rahvar M, Teng J, Kim J. Systemic Hyalinosis With Heterozygous CMG2 Mutations: A Case Report and Review of Literature. Am J Dermatopathol. 2016 May;38(5):e60-3.

4. Casas-Alba D, Martínez-Monseny A, Pino-Ramírez RM, Alsina L, Castejón E, Navarro-Vilarrubí S, et al. Hyaline fibromatosis syndrome: Clinical update and phenotype-genotype correlations. Hum Mutat. 2018 Dec;39(12):1752-63.

5. Murray J. On three peculiar cases of molluscum fibrosum in children in which one or more of the following conditions were observed: hypertrophy of the gums; enlargement of the ends of the fingers and toes; numerous connective tissue tumours on the scalp and other parts of the surface of the body, with various superficial affections of the skin. Med Chir Trans. 1873;56:235-54.

6. Denadai R, Raposo-Amaral CE, Bertola D, Kim C, Alonso N, Hart T, et al. Identification of 2 novel ANTXR2 mutations in patients with hyaline fibromatosis syndrome and proposal of a modified grading system. Am J Med Genet A. 2012 Apr;158A(4):732-42.

7. Hallikerimath S, Kale A, Kotrashetti V. Oral Juvenile Hyaline Fibromatosis: A Rare Entity. Acta Stomatol Croat. 2011;45(1):46-51.

8. Rajendran P, Karmegaraj B, Vij M, Scott JX. Unusual cause for gum hypertrophy and skin nodules in a child. BMJ Case Rep. 2015 Dec 18;2015. pii: bcr2015211506.

9. Urbina F1, Sazunic I, Murray G. Infantile systemic hyalinosis or juvenile hyaline fibromatosis? Pediatr Dermatol. 2004 MarApr;21(2):154-9.

10. Ruiz-Maldonado R, Durán-McKinster C, Sáez-de-Ocariz M, Calderón-Elvir C, Yamazaki-Nakashimada MA, Orozco-Covarrubias L. Interferon alpha-2B in juvenile hyaline fibromatosis. Clin Exp Dermatol. 2006 May;31(3):478-9. 